\section{EVALUATING SURFACE WATER QUALITY AND WATER MONITORING PARAMETERS IN THE TIEN RIVER, VIETNAMESE MEKONG DELTA}

Nguyen Thanh Giao, Vo Quang Minh*

College of Environment and Natural Resources, Can Tho University
Article history

Received

3 December 2020

Received in revised form

15 February 2021

Accepted

23 February 2021

Published online

22 April 2021

*Corresponding author vaminh@ctu.edu.vn

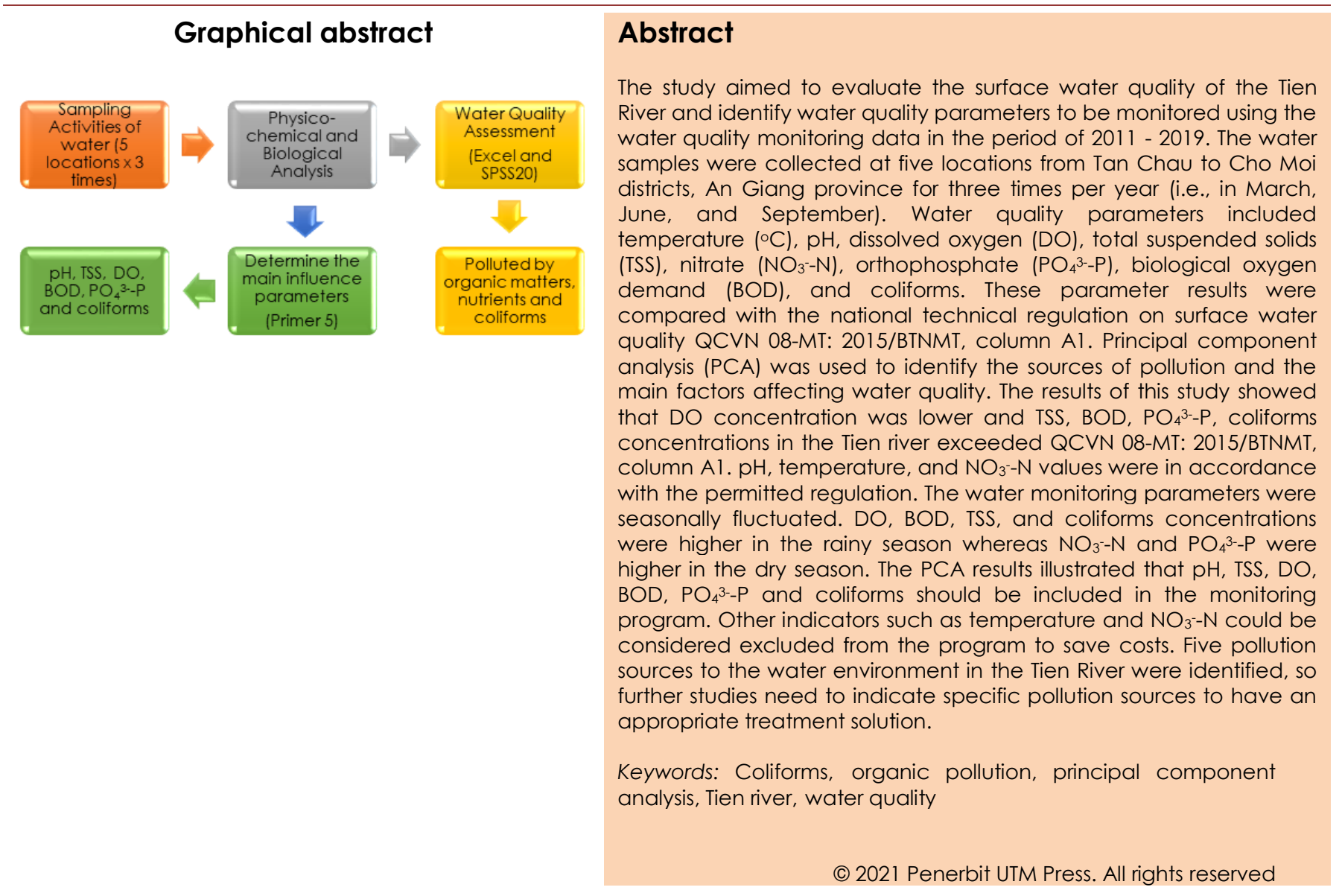

\subsection{INTRODUCTION}

The Tien River is the downstream tributary to the left of the Mekong River, flowing from Cambodia to many provinces in the Vietnamese Mekong Delta (e.g., An
Giang (in Tan Chau district), Dong Thap, Tien Giang, Vinh Long, Tra Vinh and Ben Tre provinces) and then into the South China Sea [1]. The Tien River has over $234 \mathrm{~km}$ in total official length, plays an important role in the socio-economic development strategy of the 
delta [2]. Specially, the river transports silt and nutrients to replenish the fertility of arable land and simultaneously cleans out the pollutants every year [2]. Water is an essential component for life, a change in water quality can affect the water supply for local socio-economic development activities. Therefore, water quality monitoring has an important task to ensure the effective management of water resources. Nowadays, the water monitoring program is institutionalized by countries around the world. In the same strategy, many programs have been implemented in all-important water bodies in Vietnam [3]. In the Vietnamese Mekong Delta, many monitoring points were built and located along the Tien River from the upstream in An Giang province to flowing into the sea. However, the selection of monitoring indicators that has not been conducted by any scientific analysis method mostly based on the activities of the people on both sides of the Tien River.

Principal component analysis (PCA) is a multivariate analysis technique used to assess fluctuations in water quality, identify pollution sources, and figure out significant criteria affecting the water quality [4, 5]. For instance, using 12 surface water quality parameters (e.g., pH, electrical conductivity (EC), total dissolved solids (TDS), total suspended solids (TSS), turbidity, dissolved oxygen (DO), chemical oxygen demand (COD), biochemical oxygen demand $(B O D)$, chloride $\left(\mathrm{Cl}^{-}\right)$, nitrate $\left(\mathrm{NO}_{3}-\mathrm{N}\right)$, sulfate $\left(\mathrm{SO}_{4}{ }^{2-}\right)$, orthophosphate $\left(\mathrm{PO}_{4}{ }^{3-} \mathrm{P}\right)$ in the Markina River in Philippines, the results of PCA analysis showed that surface water quality monitoring required only nine parameters (e.g., TDS, Cl-, DO, COD, BOD and $\mathrm{PO}_{4}{ }^{3-} \mathrm{P}$ ) [4]. Cho et al. (2009) [6] studied seasonal changes in the water quality on the Yeongsan Lake (in South Korea) for continuous five years including 18 monitoring parameters (e.g., temperature, $\mathrm{pH}, \mathrm{DO}$, COD, BOD, SS, TC, TN, TP, SD, Chlorophyll-a, EC, $\mathrm{NO}_{3}^{-}-\mathrm{N}$, $\mathrm{NH}_{4}{ }^{+}-\mathrm{N}, \mathrm{FIB}, \mathrm{PO}_{4}{ }^{3-}-\mathrm{P}, \mathrm{DTN}$ and DTP). The PCA results identified the five most important components corresponding to the five sources' impact on the water quality such as hydrometeorology, nitrogen loading, phosphorus loading, chlorophyll-a and FIB. Ky and Lam (2014) [7] applied PCA to assess the water quality in the Nhu Y River, Thua Thien Hue province. Water samples were collected at five sampling stations with six parameters such as temperature, DO, BOD, $\mathrm{COD}, \mathrm{NO}_{3}^{-}-\mathrm{N}$ and $\mathrm{PO}_{4}^{3-} \mathrm{P}$. The PCA results showed there were two main components that had affected changes in the water quality including Group 1 (temperature, $\mathrm{DO}, \mathrm{BOD}$ and $\mathrm{COD})$ and Group $2\left(\mathrm{NO}_{3}^{--}\right.$ $\mathrm{N}$ and $\left.\mathrm{PO}_{4}{ }^{3-} \mathrm{P}\right)$. The parameters in these two groups were proposed to be comprised in the surface water monitoring program.

Several previous studies have proven that PCA is a very useful tool to support the decision-making process in identifying pollution sources and figuring out necessary monitoring criteria. This study was conducted to assess changes in the water quality in the Tien River in An Giang province and to evaluate the monitoring criteria of surface water quality using
PCA technique from 2011 to 2019. The research results would provide important information of the surface water quality progress in the Tien River and identify necessary water monitoring parameters.

\subsection{METHODOLOGY}

\subsection{Data Collection}

The surface water quality data was collected in the period of $2011-2019$ and three times per year (e.g., March, June, and September). There were five sampling points (denoted in order of TR1 to TR5) located from Tan Chau to Cho Moi districts. The eight water quality monitoring parameters were determined including temperature $\left({ }^{\circ} \mathrm{C}\right), \mathrm{pH}$, dissolved oxygen (DO, $\mathrm{mg} / \mathrm{L}$ ), total suspended solids (TSS, $\mathrm{mg} / \mathrm{L})$, nitrate $\left(\mathrm{NO}_{3}-\right.$ $\mathrm{N}, \mathrm{mg} / \mathrm{L})$, orthophosphate $\left(\mathrm{PO}_{4}^{3-} \mathrm{P}, \mathrm{mg} / \mathrm{L}\right)$, biological oxygen demand (BOD, $\mathrm{mg} / \mathrm{L})$, and coliforms (MPN/100mL). Especially, the parameters such as temperature, $\mathrm{pH}, \mathrm{DO}$ were directly measured onsite (ADWA AD12 pH (made by Romania); DO 7031 DO meters (made by GONDO)). The remaining indicators were properly preserved and analyzed at the laboratory of the Center for Natural Resources and Environment Monitoring An Giang province using standard methods (APHA, 1998) [8].

Table 1 Description of the water monitoring locations in the Tien River in the period of 2011-2019

\begin{tabular}{|c|c|c|c|c|}
\hline Sig. & $\begin{array}{l}\text { Coordi } \\
\text { nate }\end{array}$ & Location & Properties & Reason \\
\hline TR 1 & $\begin{array}{l}10^{0} 48^{\prime} 1 \\
7.4^{\prime \prime} \mathrm{N} \\
105^{\circ} 13^{\prime} \\
45.3^{\prime \prime} \mathrm{E}\end{array}$ & $\begin{array}{l}\text { Long Thị D } \\
\text { hamlet, Tan } \\
\text { Chau town, } \\
\text { Tan Chau } \\
\text { district }\end{array}$ & $\begin{array}{l}\text { The beginning } \\
\text { section of Cai } \\
\text { Vung and Tien } \\
\text { Rivers }\end{array}$ & $\begin{array}{l}\text { To control water } \\
\text { quality in the Tien } \\
\text { river }\end{array}$ \\
\hline TR2 & $\begin{array}{l}10^{0} 43^{\prime} 8 \\
.6 " \mathrm{~N} \\
105^{0} 20^{\prime} \\
45.4^{\prime \prime} \mathrm{E}\end{array}$ & $\begin{array}{lr}\text { Phu } & \text { Hiep } \\
\text { hamlet, } & \text { Cho } \\
\text { Vam } & \text { town, } \\
\text { Phu } & \text { Tan } \\
\text { district } & \end{array}$ & $\begin{array}{l}\text { The end } \\
\text { section of Cai } \\
\text { Vung and Tien } \\
\text { Rivers }\end{array}$ & $\begin{array}{l}\text { To control water } \\
\text { quality in the Tien } \\
\text { river, where the } \\
\text { confluence of Cai } \\
\text { Vung and Tien } \\
\text { Rivers }\end{array}$ \\
\hline TR3 & $\begin{array}{l}10034^{\prime 2} \\
9.4^{\prime \prime} \mathrm{N} \\
105^{\circ} 22 \text { ' } \\
0.8^{\prime \prime} \mathrm{E}\end{array}$ & $\begin{array}{l}\text { Trung hamlet, } \\
\text { Tan Trung } \\
\text { commune, } \\
\text { Phu Tan } \\
\text { district }\end{array}$ & $\begin{array}{l}\text { The } \\
\text { confluence of } \\
\text { Vam Nao and } \\
\text { Tien Rivers }\end{array}$ & $\begin{array}{l}\text { To control water } \\
\text { quality in the Tien } \\
\text { river, where the } \\
\text { confluence of } \\
\text { Vam Nao and } \\
\text { Tien Rivers }\end{array}$ \\
\hline TR4 & $\begin{array}{l}10^{033} 9 \\
6 " \mathrm{~N} \\
105^{\circ} 26^{\prime} \\
35.3^{\prime \prime} \mathrm{E}\end{array}$ & $\begin{array}{l}\text { Long Hoa } 1 \\
\text { hamlet, Long } \\
\text { Dien } \\
\text { commune, } \\
\text { Cho Moi } \\
\text { district }\end{array}$ & $\begin{array}{ll}\text { Tien } & \text { River } \\
\text { junction } & \end{array}$ & $\begin{array}{l}\text { To control water } \\
\text { quality in the Tien } \\
\text { river, where the } \\
\text { confluence of the } \\
\text { Tien River section } \\
\text { and the Gieng } \\
\text { Islet }\end{array}$ \\
\hline TR5 & $\begin{array}{l}10^{0} 25^{\prime} 5 \\
7.8^{\prime \prime} \mathrm{N} \\
105^{\circ} 34^{\prime} \\
18.6^{\prime \prime} \mathrm{E}\end{array}$ & $\begin{array}{ll}\text { Binh } & \text { Tan } \\
\text { hamlet, } & \text { Tan } \\
\text { My commune, } & \text { Cho } \quad \text { Moi } \\
\text { district } & \end{array}$ & Gieng islet & $\begin{array}{l}\text { To control water } \\
\text { quality at the end } \\
\text { of Tien river } \\
\text { section in An } \\
\text { Giang province } \\
\text { before flowing } \\
\text { through Dong }\end{array}$ \\
\hline & & & & Thap province \\
\hline
\end{tabular}




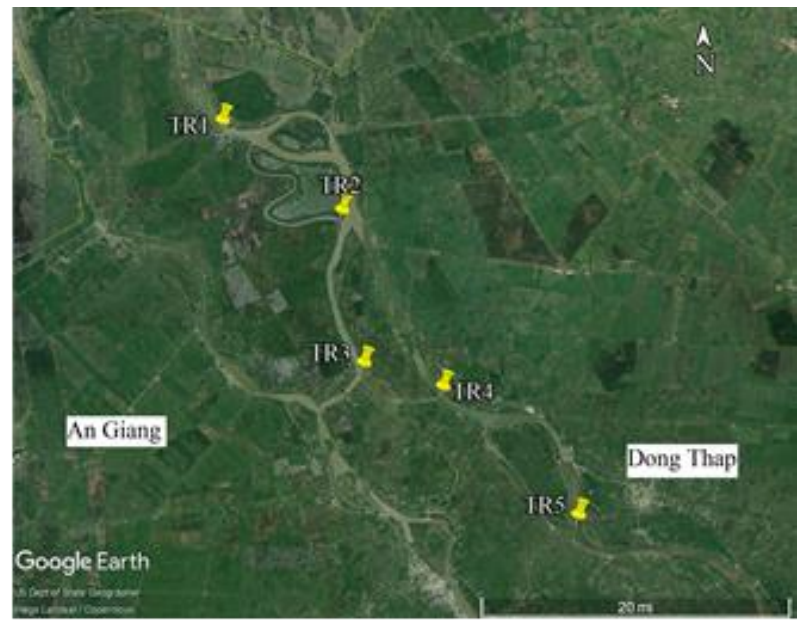

Figure 1 Map of the sampling sites

\subsection{Data Analysis}

Water quality data are presented as average, standard deviation and compared with national technical regulations on surface water quality column Al (QCVN 08-MT: 2015/BTNMT) (Table 2) [9].

Principal Component Analysis (PCA) is mainly used to reduce initial data variables that do not significantly contribute to the data variability. The PCA results will generate a new set of variables called the principal components or principal factors (PCs). The eigenvalue coefficient is used to evaluate the PCs. It means that the larger the eigenvalue coefficient, the greater the major contribution to explaining the variability of the original data. The correlation between the PCs and the original data variables is explained by weighting factors [10]. The absolute value of the weighting factor is greater than 0.75 , which means that the strong correlation between the PC and water quality parameters, from $0.75-0.5$ is an average correlation, and $0.5-0.3$ is a weak correlation [11]. The PCA analysis was analyzed using Primer 5.2 for Windows software (PRIMER-E Ltd, Plymouth, UK). Statistical comparison was performed using IBM SPSS Statistics for Windows, Version 20.0 (IBM Corp., Armonk, NY, USA). The significance of the differences $(P<0.05)$ was determined by the analysis of one-way analysis of variance (ANOVA) followed by Duncan's test.

Table 2 Limited value surface water quality parameters

\begin{tabular}{ccc}
\hline Parameters & Units & Limited value (Al) \\
\hline $\mathrm{pH}$ & - & $6.5-8.5$ \\
$\mathrm{DO}$ & $\mathrm{mg} / \mathrm{L}$ & $\geq 6$ \\
$\mathrm{TSS}$ & $\mathrm{mg} / \mathrm{L}$ & 20 \\
$\mathrm{BOD}$ & $\mathrm{mg} / \mathrm{L}$ & 4 \\
$\mathrm{NO}_{3}-\mathrm{N}$ & $\mathrm{mg} / \mathrm{L}$ & 2 \\
$\mathrm{PO}^{3--} \mathrm{P}$ & $\mathrm{mg} / \mathrm{L}$ & 0.1 \\
Coliform & $\mathrm{MPN} / 100 \mathrm{~mL}$ & 2500 \\
\hline
\end{tabular}

\subsection{RESULTS AND DISCUSSION}

\subsection{Water Quality in the Tien River for the Period of $2011-2019$}

The Tien River temperature measured at five sampling points was shown in Figure 2 . The temperature for the period of 9 years was relatively stable and ranged from $28.6 \pm 0.97$ to $31.5 \pm 0.77^{\circ} \mathrm{C}$ (Figure 2a). The mean temperature among the locations ranged from $29.8 \pm 1.2$ to $30.3 \pm 1.4 \circ \mathrm{C}$ and there was no significant difference $(p>0.05)$ (Figure $2 b)$. The temperature had a slightly temporal fluctuation (Figure 2c). For instance, the temperatures in March, June, and September were $30 \pm 0.8,31 \pm 0.8^{\circ} \mathrm{C}$, and $29.5 \pm 1.1^{\circ} \mathrm{C}$, respectively. The temperature in June was higher than that of March and September and there was a statistically significant difference compared to the other two months $(p<0.05)$ (Figure 2d). The Hau River temperature varied from $27.1-32.0^{\circ} \mathrm{C}$ [12, 13 and 14] and the Mekong River temperature ranged between $19.9-32.2^{\circ} \mathrm{C}[15,16]$. There was a trend of decrease water temperature in September [12], but this fluctuation was not much large [13] because river water has the function of self-regulating temperature [17]. This temperature was in the range suitable for the development of aquatic organisms [18, 19]. Temperature is closely related to the solubility of gases such as oxygen. In which, the higher the temperature would be related to the lower the solubility of the gas but increases in the solubility of solids [20, 21]. In contrast, the higher temperature (within the tolerance ranges for the organisms), the more stimulation of growth and development of the organisms.
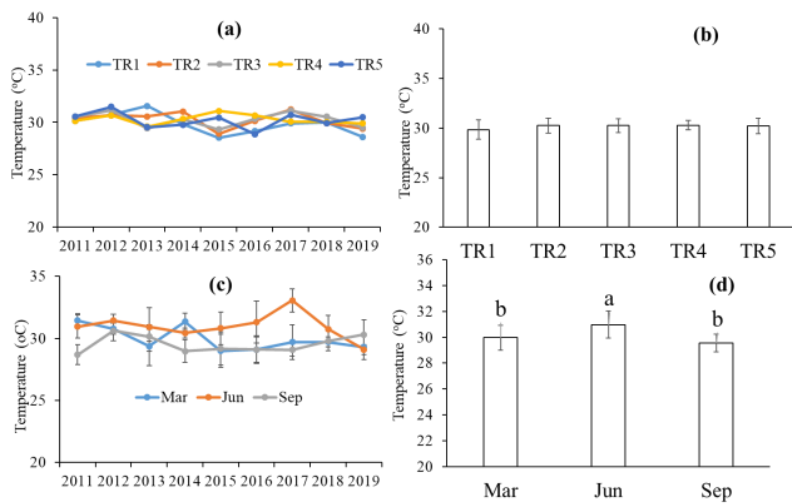

Note: Letters $a, b$ indicated significant differences at a significance level of $5 \%$.

Figure 2 Temperature in the Tien River for the period 20112019

$\mathrm{pH}$ is one of the most important and frequently used parameters to evaluate the level of water pollution, wastewater quality, water hardness, flocculation, and corrosion. Because $\mathrm{pH}$ changes lead to changes in the chemical composition of 
substances in water through precipitation, dissolving or promoting and preventing chemical reactions, biological processes occurring in water. In the study period, the $\mathrm{pH}$ value ranged from $6.7 \pm 0.1$ (in 2011) to $7.4 \pm 0.1$ (in 2018) (Figure 3a). The average value between monitoring locations ranged from $7.1 \pm 0.2$ $7.2 \pm 0.3$ (Figure $3 b$ ) and there was no significant difference by seasonal ( $p>0.05$ ) (Figure 3c). The average $\mathrm{pH}$ values in March, June, and September were $7.2 \pm 0.3,7.2 \pm 0.3$, and $7.1 \pm 0.2$, in turn (Figure $3 d)$. Some previous research showed that the canal $\mathrm{pH}$ in An Giang province from 2006 - 2009 varied from 6.9 - 7.1 [13], in the main rivers and tributaries of the Hau River in 2016 fluctuated from 6.3 - 8.0 [8] and in the Hau River section from An Giang to Hau Giang province ranged from 6.7 - 7.12 [14]. The $\mathrm{pH}$ value was in the permitted range of the national technical regulation on surface water quality QCVN 08MT:2015/BTNMT [9]. The range of $\mathrm{pH}$ values in the Tien river during 2011-2019 was suitable for the development of aquatic organisms [19].
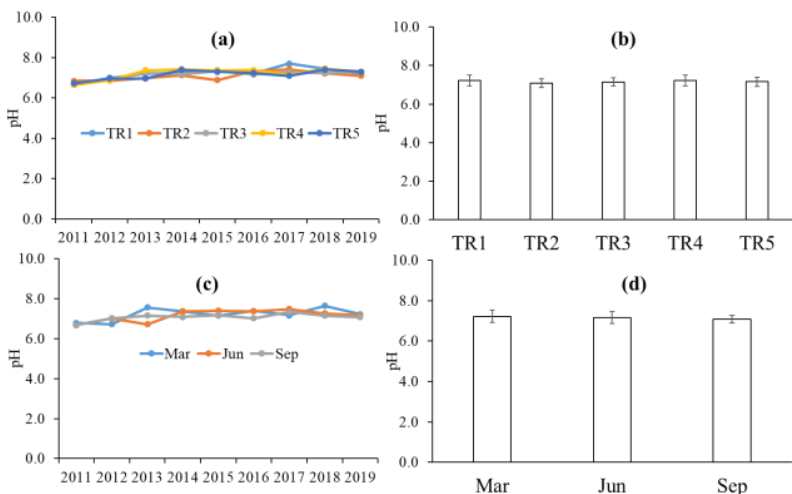

Figure $3 \mathrm{pH}$ in the Tien River for the period 201 1-2019

The total suspended solids (TSS) by temporal was in the range of $44.4 \pm 4.5$ (in 2012) to $85.9 \pm 9.4 \mathrm{mg} / \mathrm{L}$ (in 2015), reaching the average value at $67.1 \pm 3.4$ $\mathrm{mg} / \mathrm{L}$ (Figure 4a). Among the sampling locations, the average TSS for 9 years ranged from $64.0 \pm 13.0$ to $70.8 \pm 19.9 \mathrm{mg} / \mathrm{L}$ and there was no statistically significant difference ( $p>0.05$ ) (Figure 4b). Previous studies have reported that TSS has a large fluctuation among water bodies and causes water quality degradation in the Vietnamese Mekong Delta. For examples, TSS concentrations in the Hau River ranged

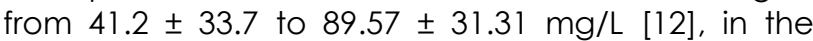
canals in An Giang province in the period of 20092016 fluctuated from $25.0 \pm 11.5$ to $93.7 \pm 28.3 \mathrm{mg} / \mathrm{L}$ [13]; particularly, TSS in the Hau River in the period of 2009 - 2016 was $40.1-68.0 \mathrm{mg} / \mathrm{L}$ [13] and in 2018 was $41.16 \pm 35.81-48.67 \pm 9.07 \mathrm{mg} / \mathrm{L}$ [14]. In Soc Trang province, TSS concentrations in canals ranged from 16 - $176 \mathrm{mg} / \mathrm{L}$ [22]. In this study, TSS concentration had a significant seasonal variation $(p<0.05)$ with the average values of $38.4 \pm 16.7 \mathrm{mg} / \mathrm{L}, 35.4 \pm 10.9 \mathrm{mg} / \mathrm{L}$, $127.5 \pm 48.3 \mathrm{mg} / \mathrm{L}$ in March, June, and September, respectively. While TSS concentrations in March and June were not significantly different ( $p>0.05)$, these two months were significantly lower $(p<0.05)$ than in that in September (Figure 4d). Lien et al. (2016) [12] and Ut et al. (2013) [23] also figured out that water quality was strongly influenced by seasonal changes in which TSS in the rainy season is always higher than that in the dry season due to the impact of rainwater runoff and erosion. It was also found that TSS in the upstream tended to be higher than that of downstream because of the flow rate and the amount of sediment contained in the water column [14]. The study results showed that TSS concentrations in the Tien River from 2011 to 2019 exceeded QCVN 08-MT:2015/BTNMT, column A1 [9] from 2.2 to 4.3 times. High TSS causes increased water treatment costs and impact on aquatic life. TSS is also a carrier that helps transport other contaminants such as pathogenic microorganisms, pesticides, antibiotics to many different places in water bodies and increase chances to exposure harmful factors.
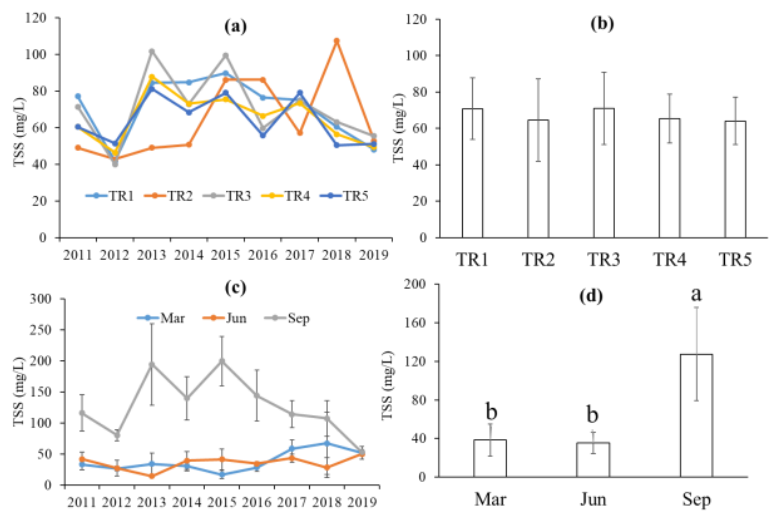

Note: Letters $a, b$ indicated significant differences at a significance level of $5 \%$.

Figure 4 TSS in the Tien River for the period of 2011-2019

The dissolved oxygen (DO) concentration in the Tien river was illustrated in Figure 5 . The DO concentrations in the studied years ranged from $4.8 \pm$ 0.4 (in 2011 ) to $6.9 \pm 0.4 \mathrm{mg} / \mathrm{L}$ (in 2014), the average concentration of $5.7 \pm 0.2 \mathrm{mg} / \mathrm{L}$ (Figure $5 \mathrm{a}$ ). This concentration among sampling sites fluctuated from $5.5 \pm 0.6$ to $6.0 \pm 0.7 \mathrm{mg} / \mathrm{L}$ (Figure $5 \mathrm{~b}$ ), and there was no statistically significant difference $(p>0.05)$. The average DO concentration in upstream flowing through An Giang province ranged from 4.0 to 5.2 $\mathrm{mg} / \mathrm{L}$ [13]. In the Hau River, the measured concentrations of DO in 2016 and 2018 were $4.8 \pm 1.1$ $-5.5 \pm 0.7 \mathrm{mg} / \mathrm{L}[12]$, and $5.29 \pm 0.33-56.5 \pm 0.56 \mathrm{mg} / \mathrm{L}$ [14], respectively. In Soc Trang province, DO in the canals was lower than that in the other study ranged from 1.7 to $6.17 \mathrm{mg} / \mathrm{L}$ [22]. The seasonal variation of DO was less than that of TSS (Figure 5c). The DO concentration observed in September $(5.5 \pm 1 \mathrm{mg} / \mathrm{L})$ was higher than that in March and June (5.6 \pm 0.3 , and $6.1 \pm 0.6 \mathrm{mg} / \mathrm{L}$, respectively) (Figure $5 \mathrm{~d}$ ). The DO concentration in the Tien River in the period of 2011 . 2019 was lower than the allowed limit of column Al 
according to QCVN 08-MT:2015/BTNMT [9]. In water bodies such as the Tien and Hau Rivers, DO concentration should be remained at least $5 \mathrm{mg} / \mathrm{L}$ to be suitable for the development of aquatic organisms [15]. DO concentration in the Tien River depends on the diffusion, the presence of phytoplankton, and organic matters. In addition, DO concentration could be used as an indicator for the organic pollution because organic matterdecomposing microorganisms require the presence of oxygen. Low oxygen levels in the watershed can lead to a loss of aquatic biodiversity. In the Tien River, the low DO could be explained by the presence of organic compounds because the Tien River has a wide surface area. The diffusion of oxygen between air and aqueous environment is maximum, and the DO release process from the photosynthesis of algae is very low compared to diffusion.
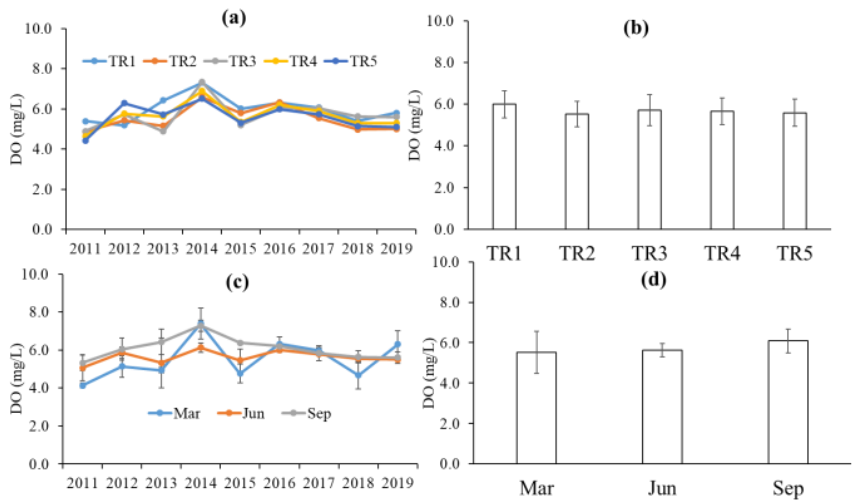

Figure 5 DO in the Tien River for the period 201 1-2019

Biochemical oxygen demand (BOD) on the Tien River from 2011 to 2019 tended to increase gradually from $5.1 \pm 0.9$ to $10.5 \pm 1.5 \mathrm{mg} / \mathrm{L}$ and had an average value of $6.7 \pm 0.3 \mathrm{mg} / \mathrm{L}$ (Figure $6 \mathrm{a}$ ). The average values among the monitoring positions ranged from $6.4 \pm 1.2$ to $7 \pm 2.5 \mathrm{mg} / \mathrm{L}$ (Figure $6 \mathrm{~b}$ ), were higher than the permitted concentration in QCVN 08-MT: 2015/BTNMT, Column A1 [9] from 1.3-2.6 times. This was consistent with the results of low DO measurements which could prove that the surface water of the Tien River was polluted by the organic matters. Previous studies reported that BOD concentration in in-field canals and the Hau River in An Giang province (was in the range of $6.6 \pm 1.2-8.2$ $\pm 2.5 \mathrm{mg} / \mathrm{L} \mathrm{[13])} \mathrm{and} \mathrm{in} \mathrm{canals} \mathrm{in} \mathrm{Soc} \mathrm{Trang} \mathrm{province}$ (was in the range of 2.2 - $22.4 \mathrm{mg} / \mathrm{L}$ [22]) were almost greater than the permitted level in QCVN 08MT:2015/BTNMT, column Al [9]. BOD by months ranged from $5.1 \pm 4.2$ to $10.5 \pm 3.9 \mathrm{mg} / \mathrm{L}$ (Figure $6 \mathrm{C}$ ). BOD concentrations in March, June, and September were respectively $6.1 \pm 1.6,5.1 \pm 2.2$, and $8.9 \pm 2.6$ $\mathrm{mg} / \mathrm{L}$, in which the $\mathrm{BOD}$ in rainy season was significantly higher than that in the dry season ( $P$ $<0.05$ ) (Figure 6d). Seasonal fluctuations of BOD, such as $B O D$ in the wet season higher than that in the dry season, were also figured out by the previous study [13]. BOD concentration has potential to cause human health risks when BOD contaminated water used as a water supply for water treatment plants. Carbon compounds could react with chlorine during disinfection to produce hazardous compounds [24]. Similar to TSS issue, organic pollution due to high BOD concentration is a common problem for water bodies in the Vietnamese Mekong Delta. There are many sources leading the BOD-contaminated water such as waste from cultivation, livestock, landfills, domestic activities, and services which directly discharge untreated wastes into surface water [16, 25-26].
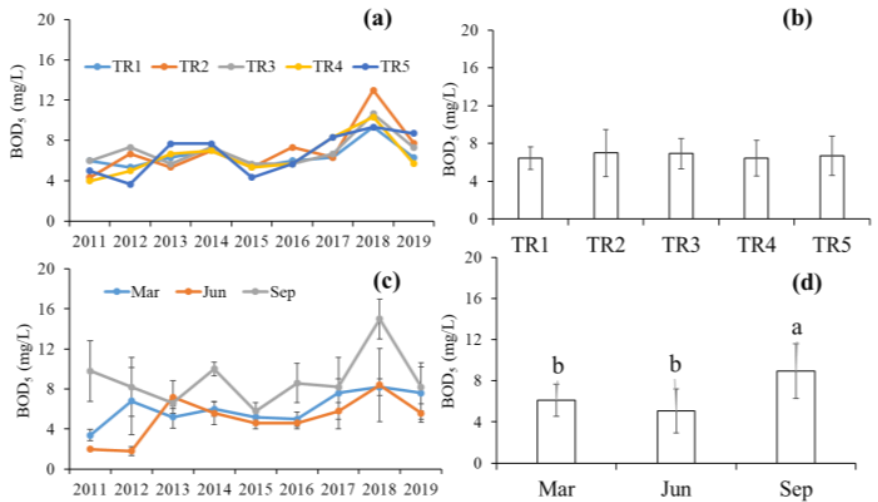

Note: Letters $a, b$ indicated significant differences at a significance level of $5 \%$.

Figure 6 BOD in the Tien River for the period 2011-2019

$\mathrm{NO}_{3}-\mathrm{N}$ concentration was highly fluctuated and tended to decrease gradually from 2011 to 2019 (Figure 7a). The values of $\mathrm{NO}_{3}^{-}-\mathrm{N}$ ranged from $0.037 \pm$ 0.006 (in 2018) to $0.371 \pm 0.175 \mathrm{mg} / \mathrm{L}$ (in 2011), averaging at $0.205 \pm 0.046 \mathrm{mg} / \mathrm{L}$. $\mathrm{NO}_{3}^{-}-\mathrm{N}$ concentrations in 2011,2012, 2014 and 2015 were higher than that in the following years. The average $\mathrm{NO}_{3}-\mathrm{N}$ values for 9 years were highest at the TR4 position (0.259 $\pm 0.187 \mathrm{mg} / \mathrm{L})$ and the lowest at the TR5 position (0.146 $\pm 0.106 \mathrm{mg} / \mathrm{L}$ ) (Figure 7b). $\mathrm{NO}_{3}{ }^{-}-\mathrm{N}$ concentrations in March, June and September were $0.151 \pm 0.07,0.229 \pm 0.117$, and $0.181 \pm 0.092 \mathrm{mg} / \mathrm{L}$, respectively (Figure $7 \mathrm{~d}$ ). The highest concentration of $\mathrm{NO}_{3}-\mathrm{N}$ in June was a result of the dry season and also the time for fertilizing the fields [23]. Previous studies have shown that $\mathrm{NO}_{3}^{-}-\mathrm{N}$ concentration in the $\mathrm{Hau}$ River ranged from 0.002 - $0.395 \mathrm{mg} / \mathrm{L}$ [12], canals in An Giang province ranged from $0.31 \pm 0.3$ to $0.58 \pm$ $0.64 \mathrm{mg} / \mathrm{L}$ [13], canals in Soc Trang province was 0.05 - $0.14 \mathrm{mg} / \mathrm{L}$ [22]. It was found that NO3--N in the water bodies in the Mekong delta was temporal and spatial fluctuation; however, this concentration was still in accordance with the permitted standard of QCVN 08-MT: 2015/BTNMT, column Al (2 mg/L) [9]. When $\mathrm{NO}_{3}^{-}-\mathrm{N}$ concentration is greater than $0.7 \mathrm{mg} / \mathrm{L}$ and in the range of $0.2-10 \mathrm{mg} / \mathrm{L}$, it has the potential to cause eutrophication and is suitable for aquatic life $[15,19]$. With the current research results, $\mathrm{NO}_{3}^{-}-\mathrm{N}$ 
in surface water in the Tien river is still acceptable and does not cause eutrophication and affects human health.
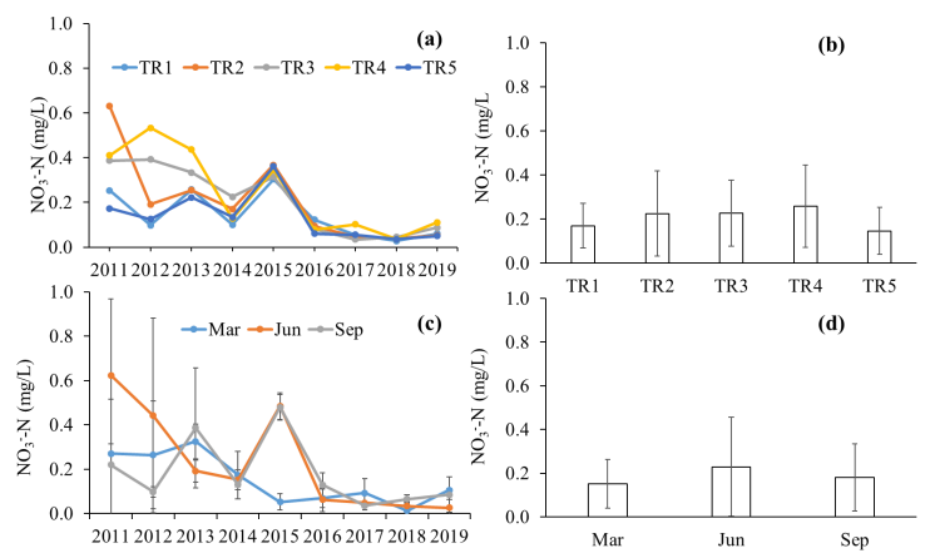

Figure $7 \mathrm{NO}_{3}^{--} \mathrm{N}$ in the Tien River for the period 2011-2019

$\mathrm{PO}_{4}^{3--} \mathrm{P}$ concentration in the Tien River from 2011 to 2019 was in the range of $0.038 \pm 0.014$ (in 2012) to $0.183 \pm 0.105 \mathrm{mg} / \mathrm{L}$ (in 2014) with the average of 0.107 $\pm 0.017 \mathrm{mg} / \mathrm{L}$ (Figure 8a). These concentrations among the study locations from TR 1 to TR5 were 0.101 $\pm 0.078,0.125 \pm 0.107,0.084 \pm 0.044,0.101 \pm 0.046$ $0.122 \pm 0.047 \mathrm{mg} / \mathrm{L}$, respectively, with the highest one at TR2 and the lowest one at TR3 (Figure 8b). The average values of $\mathrm{PO}_{4}^{3-} \mathrm{P}$ over the 9-year periods in March, June and September were $0.085 \pm 0.061$, $0.125 \pm 0.117$, and $0.109 \pm 0.071 \mathrm{mg} / \mathrm{L}$ (Figure $8 \mathrm{~d}$ ), and there was no a statistically significant difference ( $p$ $>0.05)$. The value of dissolved phosphorus on canals in the field and the Hau River in An Giang province ranged from 0.02 to $0.47 \mathrm{mg} / \mathrm{L}$ [13], in the Hau River section from An Giang to Hau Giang provinces 0.04 $0.11 \mathrm{mg} / \mathrm{L}$ [14], canals in Soc Trang province 0.05 - 0.9 $\mathrm{mg} / \mathrm{L}$ [22]. These studies have demonstrated that $\mathrm{PO}_{4}{ }^{3-} \mathrm{P}$ in surface water in the Mekong Delta has exceeded the QCVN 08-MT: 2015/BTNMT, column A1 [9]. Therefore, $\mathrm{PO}_{4}{ }^{3-}-\mathrm{P}$ pollution could result in negative impact on the water environment of the Tien River and other water bodies.
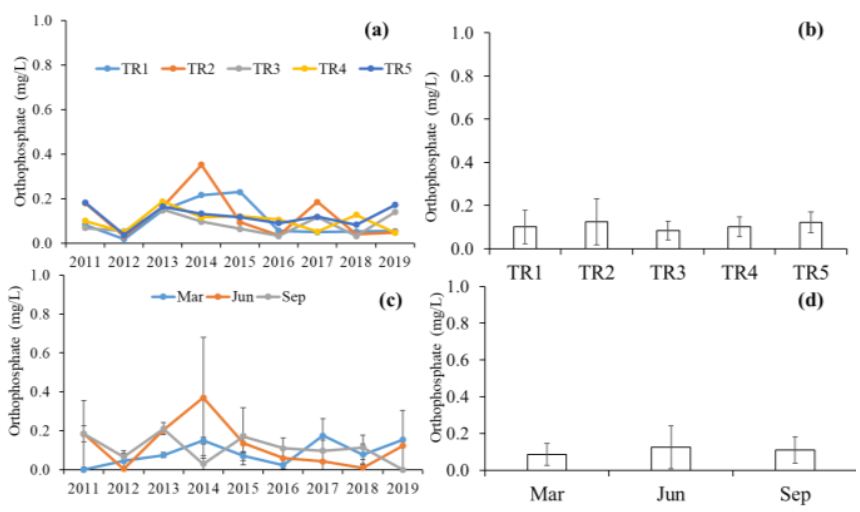

Figure $8 \mathrm{PO}_{4}^{3--} \mathrm{P}$ in Tien River for the period 201 1-2019
The number of coliforms was in the increasing trend at all positions by the time, with values from $2621 \pm$ 2379 to $11968 \pm 5615 \mathrm{MPN} / 100 \mathrm{~mL}$ (Figure 9a) which exceeded QCVN 08-MT:2015/BTNMT, column A1 [9] from 1.1 to 6.5 times. The average coliforms denisity among collecting sites for 9 years was greater than the standard from 2.2 to 5.7 times. In the same trend, Ly and Giao (2018) [13] showed that coliforms in surface water of An Giang province in the period of 2009 - 2016 exceeded the permitted limit $2.14-7.02$ times. In Soc Trang province, coliforms in canals were beyond from 1 to 36 times than the standard [22]. The average coliforms densities in March, June, and September were respectively $9607 \pm 10729$ $\mathrm{MPN} / 100 \mathrm{~mL}, 6336 \pm 5546 \mathrm{MPN} / 100 \mathrm{~mL}, 19983 \pm 27110$ MPN/100mL; in which, the coliforms in rain season was higher than that in the dry season (Figure 9d). In general, the Tien River was contaminated with microorganisms and this water source must be appropriately treated before use. The presence of coliforms indicates that the Tien River is receiving waste excreted from humans and animals.
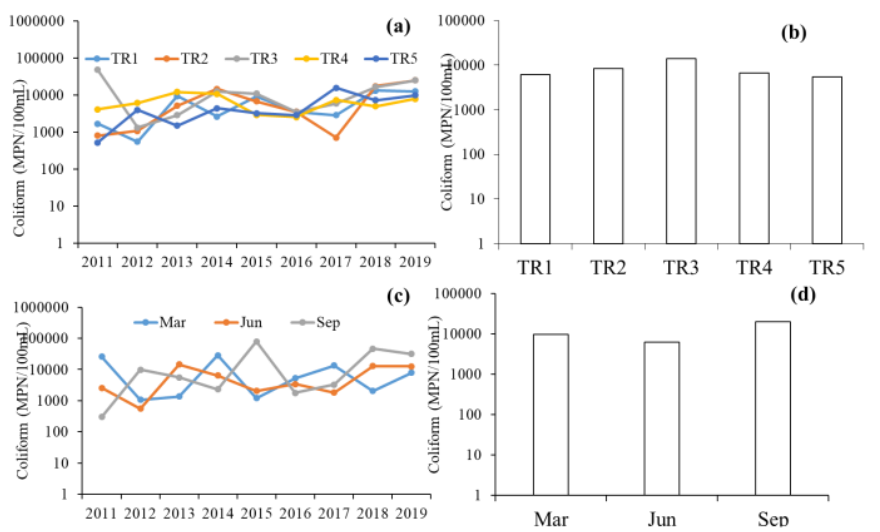

Figure 9 Coliforms in the Tien River for the period 2011 -2019

3.2 Identification of Main Water Parameters Influencing Water Quality in the Tien River for the Period 2011-2019

The results of PCA showed that there were five principal components explaining $94.9 \%$ of the water quality fluctuation in the Tien River in the period of 2011-2019 (Table 3). The PC1, PC2, PC3, PC4, and PC5 explained changes in the water quality over a 9year period with rates of $34.0 \%, 27.9 \%, 15.0 \%, 9.7 \%$ and $8.4 \%$, respectively. The $\mathrm{PCl}$ showed the fluctuations of temperature (-0.399), $\mathrm{pH}(-0.375)$, TSS ($0.509)$, DO $(-0.314)$, and BOD $(-0.485)$ at weak correlations. PC2 also explained the fluctuations of temperature (-0.453), pH (-0.349) DO (0.359), $\mathrm{NO}_{3}^{-}-\mathrm{N}$ ($0.476)$ and $\mathrm{PO}_{4}{ }^{3-}-\mathrm{P}(-0.426)$ at weak correlations. $\mathrm{PC} 3$ was poorly correlated with $\mathrm{NO}_{3}^{-}-\mathrm{N}(0.476), \mathrm{PO}_{4}^{3-}-\mathrm{P}$ ($0.318)$, and had a moderate correlation with coliforms (-0.736). PC4 had a weak correlation with $\mathrm{pH}$ (0.536), $\mathrm{NO}^{-}-\mathrm{N}(-0.375)$ and a moderate correlation with $\mathrm{PO}_{4}^{3-}-\mathrm{P}(-0.637)$. PC4 had a weak 
correlation with coliforms (-0.428) and average correlation with DO $(0.655)$ and BOD $(-0.561)$. The PCA results indicated that each water quality parameter was influenced by at least five PCs. Each PCs is representative for a source of pollution [5]. Therefore, the water quality parameters that were the average or high correlation with PCs should be included in the monitoring program [11]. In this study, 6 water quality parameters (e.g., pH, TSS, DO, BOD, $\mathrm{PO}_{4}{ }^{3-} \mathrm{P}$ and coliforms) should be included in the monitoring program because of their main impacts on the Tien River. Besides, monitoring indicators such as temperature and $\mathrm{NO}_{3}{ }^{-} \mathrm{N}$ might be ignored. This can help to save time and cost in the monitoring process. These results were consistent with the water quality assessment discussed in the previous section in the Tien River, TSS, DO, BOD, $\mathrm{PO}_{4}^{3--} \mathrm{P}$ and coliforms exceeded QCVN 08-MT: 2015/BTNMT [9].

Table 3 Main water parameters affecting water quality in the Tien River

\begin{tabular}{lccccc}
\hline Parameters & $\mathrm{PCl}$ & $\mathrm{PC2}$ & $\mathrm{PC3}$ & $\mathrm{PC4}$ & $\mathrm{PC5}$ \\
\hline Temp & $\mathbf{- 0 . 3 9 9}$ & $\mathbf{- 0 . 4 5 3}$ & -0.124 & 0.208 & -0.021 \\
pH & $\mathbf{- 0 . 3 7 5}$ & $\mathbf{- 0 . 3 4 9}$ & -0.219 & $\mathbf{0 . 5 3 6}$ & 0.124 \\
$\mathrm{TSS}$ & $\mathbf{- 0 . 5 0 9}$ & 0.298 & 0.101 & -0.162 & -0.205 \\
$\mathrm{DO}$ & $\mathbf{- 0 . 3 1 4}$ & $\mathbf{0 . 3 5 9}$ & -0.208 & -0.264 & $\mathbf{0 . 6 5 5}$ \\
$\mathrm{BOD}$ & $\mathbf{- 0 . 4 8 5}$ & 0.216 & 0.116 & -0.105 & $\mathbf{- 0 . 5 6 1}$ \\
$\mathrm{NO}_{3}{ }^{-}-\mathrm{N}$ & 0.070 & $\mathbf{- 0 . 4 7 6}$ & $\mathbf{0 . 4 7 6}$ & $\mathbf{- 0 . 3 7 5}$ & -0.076 \\
$\mathrm{PO}_{4}{ }^{3-}-\mathrm{P}$ & -0.198 & $\mathbf{- 0 . 4 2 6}$ & $\mathbf{- 0 . 3 1 8}$ & $\mathbf{- 0 . 6 3 7}$ & 0.100 \\
Coliforms $^{\text {Eigenvalues }}$ & 0.252 & 0.029 & $\mathbf{- 0 . 7 3 6}$ & -0.126 & $\mathbf{- 0 . 4 2 8}$ \\
\%Variation & 2.72 & 2.23 & 1.20 & 0.77 & 0.67 \\
\%Cum. Variation & 34.0 & 27.9 & 15.0 & 9.7 & 8.4 \\
\hline
\end{tabular}

\subsection{CONCLUSION}

In this study, the results showed that average concentrations of TSS, BOD, PO4 ${ }^{3-}-\mathrm{P}$, coliforms and DO in the period of 2011 to 2019 were much greater than the permitted levels in QCVN 08-MT: 2015/BTNMT, column Al. It means that the surface water quality in the Tien River has been polluted by organic matters, nutrients and coliforms. The concentrations of some water monitoring parameters (e.g., DO, BOD, TSS and coliforms) in the rainy seasons were higher than that in the dry seasons. In contrast, $\mathrm{NO}_{3}-\mathrm{N}$ and $\mathrm{PO}_{4}^{3-} \mathrm{P}$ concentrations were higher in the dry seasons. The $\mathrm{PCA}$ results indicated that $\mathrm{pH}, \mathrm{TSS}, \mathrm{DO}, \mathrm{BOD}, \mathrm{PO}_{4}^{3--} \mathrm{P}$ and coliforms parameters should be included in the monitoring program while others (i.e., temperature and $\mathrm{NO}_{3}-\mathrm{N}$ ) might be excluded to save monitoring costs. The identification of the principal components effect on the water quality was in accordance with the previous water quality assessment of the Tien River. Moreover, there were at least five pollution sources in the Tien River. Therefore, further studies need to identify these pollution sources and propose appropriate solutions to prevent pollution and maintain the surface water quality in the Tien River.

\section{Acknowledgement}

The authors would like to thank the Department of Natural Resources and Environment An Giang province for providing water monitoring data. All opinions expressed in this paper represent the scientific and personal views of the authors and do not necessarily reflect the views of the data provider.

\section{References}

[1] Hoanh, T. P. 2015. Assessing the Situations and Causes of Riverbank Erosion of Tien River in Dong Thap Province. Natural Science and Technology. 20: 61-67.

[2] Quynh, H. N. N., Khoi, D. N., Hoai, H. C., Bay, N. T. 2018. Application of Remote Sensing and GIS for Riverbank Assessment in the Bassac and Mekong Rivers. Journal of Hydrometeorology. 6: 12-22.

[3] Prime Minister. 2007. Decision No. 16/2007/QD-TTG dated January 29, 2007 Approving Master Plan for National Natural Resources and Environment Monitoring Network Up to 2020.

[4] Vega, M., Pardo, R., Barrado, E. and Debán, L. 1998. Assessment of Seasonal and Polluting Effects on the Quality of River Water by Exploratory Data Analysis. Water Research. 32: 3581-3592. DOI: https://doi.org/10.1016/S0043-1354(98)00138-9.

[5] Chounlamany, V., Tachuling, M. A. and Inove, T. 2017. Spatial and Temporal Variation of Water Quality of a Segment of Marikina River Using Multivariate Tsatistical Analyses. Water Science \& Technology. 76: 1510-1522. DOI: https://doi.org/10.2166/wst.2017.279.

[6] Cho, K. H., Park, Y., Kang, J. H., Ki, S. J., Cha, S., Lee, S. W. and Kim, J. H. 2009. Interpretation of Seasonal Water Quality Variation in the Yeongsan Reservoir, Korea using Multivariate Statistical Analyses. Water Science \& Technology. 59: 2219-2226.

DOI: https://doi.org/10.2166/wst.2009.248

[7] Ky, N. M. and Lam, N. H. 2014. Using multivariate Statistical Techniques to Assess Water Quality of Nhu Y river in Thua Thien Hue Province. Journal of Science and Technology Development. 17: 50-60. (In Vietnamese).

DOI:https://doi.org/https://doi.org/10.32508/stdj.v17i2.1302

[8] American Public Health Association. 1998. Standard Methods for the Examination of Water and Wastewater. 20th Edition. USA: Washington DC.

[9] Ministry of Environment and Natural Resources (MONRE). 2015. National Technical Regulation on Surface Water Quality (QCVN 08-MT: 2015/BTNMT). Hanoi, Vietnam: Ministry of Natural Resources and Environment (MONRE).

[10] Feher, I. C., Zaharie, M and Oprean, I. 2016. Spatial and Seasonal Variation of Organic Pollutants in Surface Water Using Multivariate Statistical Techniques. Water Science \& Technology. 74: 1726-1735. DOI: https://doi.org/10.2166/wst.2016.351.

[11] Liu, C. W., Lin, K. H. and Kuo, Y. M. 2003. Application of Factor Analysis in the Assessment of Groundwater Quality in a Blackfoot Disease Area in Taiwan. Science of the Total Environment. 313: 77-89. DOI: https://doi.org/10.1016/S0048-9697(02)00683-6.

[12] Lien, N. T. K., Huy, L. Q., Oanh, D. T. H., Phu, T. Q., Ut, V. N. 2016. Water Quality in Mainstream and Tributaries of Hau River. Journal of Science Can Tho University. 43: 68-79. DOI: 10.22144/ctu.jvn.2016.138.

[13] Ly, N. H. T., and Giao, N. T. 2018. Surface Water Quality in Canals in an Giang Province, Viet Nam, from 2009 to 2016. Journal of Vietnamese Environment. 10(2): 113-119. DOI: https://doi.org/10.13141/jve.vol10.no2.pp113-119.

[14] Giao, N T. 2020. Evaluating Current Water Quality Monitoring System on Hau River, Mekong Delta, Vietnam 
using Multivariate Statistical Technique. Journal of Applied Environmental Research. 42(1): 14-25.

DOI: $h$ ttps://doi.org/10.35762/AER.2020.42.1.2.

[15] Ongley, E. D. 2009. Chapter 12: Water Quality of the Lower Mekong River. In: Campbell, I.C. (ed.): The Mekong: Biophysical Environment of an International River Basin. Aquatic Ecology, Academic Press. 297-320. DOI: https://doi.org/10.1016/B978-0-12-374026-7.00012-7.

[16] Mekong River Commission. 2015. Report of Lower Mekong Regional Water Quality Monitoring. MRC Technical Paper No.51.

[17] Smith, P., Ashmore, M. R., Black, H. I. J., Burgess, P. J., Evans, C. D., Quine, T. A., Thomson, A. M., Hicks, K., and Orr, H. G. 2013. The Role of Ecosystems and Their Management in Regulating Climate, and Soil, Water and Air Quality. Journal of Applied Ecology. 50: 812-829. DOI: https://doi.org/10.1111/1365-2664.12016.

[18] Boyd, C. E. 1998. Water Quality for Pond Aquaculture. Department of Fisheries and Allied Aquacultures. Alabama, USA: Auburn University.

[19] Phu, T. Q. and Ut, V. N. 2006. Water Quality for Pond Aquaculture. Can Tho University: College of Aquaculture and Fisheries. (In Vietnamese).

[20] Zhou, F., Liu, Y. and Guo, H. 2007. Application of Multivariate Statistical Methods to the Water Quality Assessment of the Watercourses in the Northwestern New Territories, Hong Kong. Environmental Monitoring and Assessment. 132: 1-13.

DOI: https://doi.org/10.1007/s10661-006-9497-x.
[21] Breitburg, D. L., J. Salisbury, J. M. Bernhard, W. J. Cai and S. Dupont et al. 2015. And on Top of All That... Coping with Ocean Acidification in the Midst of Many Stressors. Oceanography. 28(2): 48-61.

[22] Tuan, D. D. A., Thu, B. A., and Trung, N. H. 2019. Assessing Quality of Surface Water for Urban Water Supply Source for Soc Trang City. Scientific Journal of Can Tho University. 4A: 61-70. (In Vietnamese). DOI: 10.22144/ctu.jvn.2019.096.

[23] Ut, V. N., Loan, N. B., Giang, H. T., Oanh, D. T. H., Lien, N. T. K., Quoc, N. B., Ngoan, N. V., Hoa, A. V., Tu, P. T. C. 2013. Study on Measures to Limit the Growth of Limnoperna fortunei Living on Cipangopaludina lecithoides in Cho Lach District, Ben Tre. Final Report on Ministerial-level Projects. 100 pages. (In Vietnamese).

[24] Ratpukdi, T., Sinora, S., Kiattisaksiri, P., Punyapalakul, P. Siripattanakul-Ratpukdi, S. 2019. Occurrence of Trihalomethanes and Haloacetonitriles in Water Distribution Networks of Khon Kaen Municipality, Thailand. Water Supply. 19(6): 1748-1757. DOI: https://doi.org/10.2166/ws.2019.049.

[25] Chea, R., Grenovillet, G. and Lek, S. 2016. Evidence of Water Quality Degradation in Lower Mekong Basin Revealed by Self-Organizing Map. DOl: https://doi.org/10.1371/journal.pone.0145527.

[26] Nhien, H. T., \& Nguyen, G. T. 2019. Environmental Soil, Water, and Sediment Quality of Dong Thang Landfill in Can Tho City, Vietnam. Applied Environmental Research. 41 (2): 73-83.

DOI: https://doi.org/10.35762/AER.2019.41.2.7. 